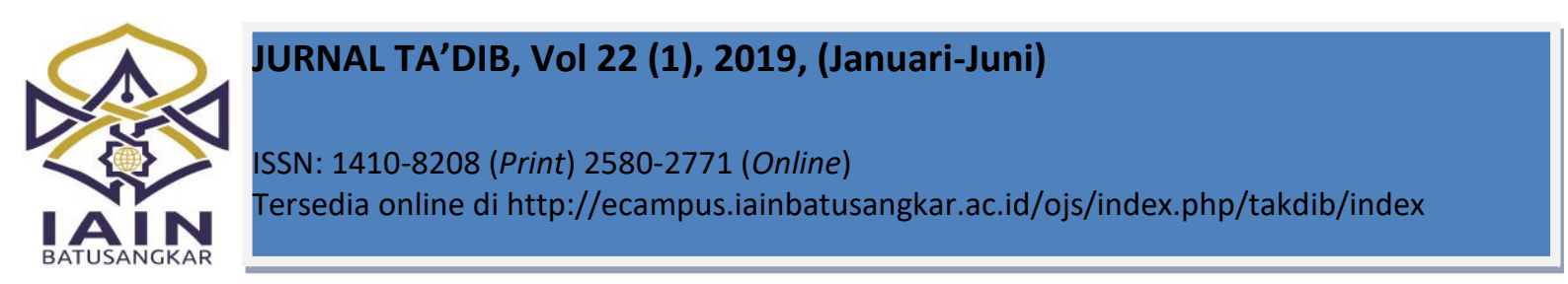

\title{
Pengaruh Media Visual Proyeksi Power Point dan Minat terhadap Hasil Belajar Peserta Didik
}

\author{
Siska Febriyanti $\mathbf{S}^{*}$ ) \\ Institut Agama Islam Negeri Batusangkar, \\ Sumatera Barat, Indonesia \\ e-mail: siska_feb@ymail.com
}

*) Corresponding Author

\begin{abstract}
Abstrak: This study aims to reveal: (1) the effect of visual media projection with Power Point on Economics learning outcomes, (2) the effect of students' learning interest on their Economics learning outcomes, (3) the interaction between media used and learning interest students' Economics learning outcomes in MAN 2 Batusangkar. The type of research is Quasy Experiment using factorial $2 \times 2$ design. The population was grade $X$ students at MAN 2 Batusangkar. The sampling technique was cluster sampling; class $X-2$ as the experimental class and class $X-5$ as the control class. Data analysis techniques are descriptive analysis and inductive analysis using two-way ANOVA. The results of the study show: (1) the students taught using Visual Media Projection with Power Point have higher learning outcomes compared to those taught with NonProjection Visual Media with Chart, (2) the students having high interest in learning gained higher Economics learning outcomes than those with low interest in learning, and (3) There is no interaction between the use of instructional media and learning interest in students' learning outcomes in Economics. Finally, it is recommended that teachers should use computerbased learning media, such as visual media projecting Power Point effectively as an alternative to improve students' learning outcomes.
\end{abstract}

Kata Kunci: Media, Power point, Insterest, Learning outcome

\section{PENDAHULUAN}

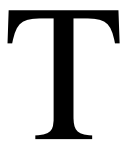
lidak dapat disangkal bahwa penggunaan media diperlukan untuk membantu usaha tenaga pendidik dalam meningkatkan hasil belajar peserta didik. Mutu pendidikan dapat dilihat dari hasil belajar yang telah dicapai oleh peserta didik, karena indikator keberhasilan peserta didik dapat dilhat dari hasil belajar yang diperoleh oleh peserta didik tersebut. Syafruddin, (2004) menyatakan hasil belajar yang diperoleh adalah hasil dari proses pada saat kegiatan belajar, misalnya penguasaan pengetahuan tentang fakta atau kenyataan, konsep, istilah, pendapat dan lain-lain. Jadi, dari uraian tersebut bisa diambil kesimpulan bahwa hasil belajar merupakan hasil yang didapatkan oleh peserta didik setelah mengikuti proses belajar mengajar yang bisa dilihat dari adanya perubahan prilaku peserta didik, baik dari segi pengetahuan atau sikap peserta didik. Berdasarkan hasil belajar yang telah diperoleh, dari sembilan lokal kelas $\mathrm{X}$ di MAN 2 Batusangkar, umumnya masih banyak peserta didik yang belum mencapai nilai tuntas dengan KKM 75. Setiap lokal dominan memperoleh nilai yang tidak tuntas. Kemudian dapat dilihat bahwa dari 9 lokal kelas $X$, nilai rata-rata tertinggi terlihat pada kelas X-5 yaitu sebesar 74,06 dengan tingkat ketuntasan peserta didik sebesar 48,39\%, 
sedangkan nilai rata-rata terendah terlihat pada kelas X-9 yaitu sebesar 61,70 dengan tingkat ketuntasan peserta didik sebesar $20,00 \%$. Ini memperlihatkan rendahnya hasil belajar Ekonomi peserta didik kelas $\mathrm{X}$ di MAN 2 Batusangkar. Hal ini mengindikasikan bahwa terdapat permasalahan di dalam proses pembelajaran.

Slameto (2003) mengungkapkan, pada umumnya hasil belajar dapat dipengaruhi oleh dua faktor, yaitu faktor internal dan faktor eksternal. Dengan rendahnya hasil belajar dari peserta didik kelas X. MAN 2 Batusangkar, diduga dapat disebabkan karena dua faktor tersebut, baik itu faktor internal seperti intelegensi, minat, motivasi, dan sikap peserta didik, maupun faktor eksternal, seperti kendala tenaga pendidik dalam menyajikan materi pada proses pembelajaran, misalnya dalam mengelola pembelajaran, penggunaan metode dan media pembelajaran. Media pembelajaran memiliki arti yang sangat penting dalam pembelajaran, untuk mempermudah dalam menyampaikan materi pembelajaran.

Ekonomi merupakan mata pelajaran yang banyak memaparkan konsep dan materi-materi yang bersifat teoritis. Jika materi Ekonomi disampaikan hanya dengan penjelasan atau dengan metode ceramah dari guru, maka ini akan membuat peserta didik merasa bosan dalam mengikuti pembelajaran Ekonomi. Dengan menggunakan media pembelajaran, diharapkan dapat meningkatkan efektivitas belajar peserta didik dalam mengikuti pembelajaran Ekonomi sehingga hasil belajar Ekonomi juga dapat ditingkatkan. Ini sesuai dengan yang diungkapkan oleh (Hamalik, 2004), yang menyatakan bahwa dengan menggunakan media dalam proses pembelajaran, maka akan dapat meningkatkan efisiensi proses dan mutu hasil belajar. Berdasarkan pengamatan melalui wawancara yang telah dilakukan, guru masih ada yang belum menggunakan media dalam proses pembelajaran, seperti media visual proyeksi dengan Power Point. Ini terlihat dari 4 orang guru Ekonomi yang ada di
MAN 2 Batusangkar, hanya 1 orang guru yang sering menggunakan media visual proyeksi dengan Power Point saat proses pembelajaran berlangsung, ini berarti hanya sekitar $25 \%$ guru yang sering menggunakan media.

Selain itu, dalam pembelajaran Ekonomi masih terlihat rendahnya minat belajar peserta didik. Bedasarkan wawancara yang telah dilakukan kepada guru Ekonomi, rendahnya minat belajar peserta didik dapat terlihat dengan masih ada peserta didik yang masih sangat jarang untuk bertanya, masih adanya peserta didik yang berbicara dengan temannya, dan tidur-tiduran di kelas saat pelajaran berlangsung. Sikap peserta didik yang seperti ini, memperlihatkan rendahnya minat belajar peserta didik dalam mengikuti pembelajaran Ekonomi. Faktor minat merupakan salah satu faktor yang sangat penting untuk meningkatkan hasil belajar Ekonomi peserta didik. Peserta didik yang memiliki minat belajar tinggi dalam belajar Ekonomi akan berusaha untuk mengikuti pembelajaran Ekonomi sebaik mungkin dan begitu sebaliknya. Tujuan penelitian ini adalah untuk mengetahui: Pengaruh interaksi Media Visual Proyeksi Power Point terhadap Hasil Belajar Ekonomi Peserta didik kelas X di MAN 2 Batusangkar, Pengaruh Minat Belajar terhadap Hasil Belajar Ekonomi Peserta didik kelas $X$ di MAN 2 Batusangkar, dan Interaksi antara Penggunaan Media dengan Minat Belajar terhadap Hasil Belajar Ekonomi Peserta didik kelas X di MAN 2 Batusangkar.

\section{METODE PENELITIAN}

Penelitian ini berjenis penelitian eksperimen semu (quasy experiment) dengan desain factorial $2 \times 2$. Populasi dalam penelitian ini adalah peserta didik kelas $\mathrm{X}$ di MAN 2 Batusangkar. Penentuan kelas sampel diambil dengan cara memberikan angket minat kepada seluruh populasi, kemudian dihitung rata-rata minat dari masing-masing kelas dan dipilih dua kelas yang memiliki rata-rata minat yang mendekati dan dengan teknik cluster, 
sehingga terpilih 2 kelas, yaitu kelas $\mathrm{X}-2$ sebagai kelas eksperimen sebanyak 32 orang dan X-5 sebagai kelas kontrol sebanyak 31 orang. Teknik pengumpulan data penelitian ini dengan melakukan eksperimen langsung di kelas kemudian diberikan tes untuk mendapatkan hasil belajar peserta didik.

Analisis penelitian ini menggunakan analisis deskriptif dan induktif. Analisis deskriptif dilakukan pada semua variabel yang diteliti dan untuk variabel hasil belajar dideskriptifkan dengan cara menghitung mean, median, modus, nilai maximal, nilai minimal, standar deviasi dan koefisien varians. Sedangkan data variabel minat belajar terhadap mata pelajaran Ekonomi dengan cara penentuan tingkat capaian responden pada masing-masing indikator dengan membandingkan skor rata-rata dengan skor masing-masing dikalikan $100 \%$. Untuk analisis induktif dilakukan uji normalitas dan homogenitas data, setelah itu baru dilakukan uji hipotesis untuk menjawab hipotesis sebelumnya. Hipotesis statistik yang diuji dalam penelitian ini adalah sebagai berikut:

a. Pengaruh penggunaan media visual proyeksi dengan Power Point terhadap hasil belajar peserta didik, dimana setelah diolah data apabila $\alpha>0,05$, maka Ho diterima yang berarti tidak ada pengaruh penggunaan media visual proyeksi dengan Power Point dengan hasil belajar peserta didik dan begitu sebaliknya, apabila $\alpha<$ 0,05 berarti penggunaan media visual proyeksi dengan menggunakan power point ada pengaruh terhadap hasil belajar mata pelajaran Ekonomi peserta didik.

b. Pengaruh minat belajar, setelah diberikan angket kepada peserta didik dan diolah, kemudian dilihat hasil belajar peserta didik selanjutnya. Apabila hasilnya $\alpha>$ 0,05 maka Ho diterima yang berarti minat belajar tidak berpengaruh terhadap hasil belajar peserta didik dan begitu sebaliknya, apabila $\alpha<0,05$ maka Ho ditolak yang berarti adanya pengaruh minat belajar dengan hasil belajar peserta didik. c. Interaksi penggunaan media dengan minat belajar, setelah dilakukan proses pembelajaran dan minat peserta didik telah didapat maka dilakukan pengolahan data guna melihat interaksi antara penggunaan media dengan minat belajar, apabila nilai $\alpha>0,05$, maka Ho diterima berarti tidak ada interaksi penggunaan media dengan minat belajar, dan sebaliknya apabila $\alpha<0,05$, maka Ho ditolak yang berarti adanya interaksi penggunaan media dengan minat belajar.

\section{HASIL DAN PEMBAHASAN}

Berdasarkan angket yang telah disebarkan pada kedua kelas sampel, diperoleh nilai minat belajar peserta didik terhadap mata pelajaran Ekonomi sebagai berikut.

Tabel 1. Deskripsi Variabel Minat Belajar Peserta didik

\begin{tabular}{|c|c|c|c|}
\hline No & Indikator & $\begin{array}{c}\text { TCR (\%) } \\
\text { Kelas } \\
\text { Eksperimen }\end{array}$ & $\begin{array}{c}\text { TCR }(\%) \\
\text { Kelas } \\
\text { Kontrol } \\
\end{array}$ \\
\hline 1 & Perasaan Senang & 72,50 & 73,68 \\
\hline 2 & $\begin{array}{l}\text { Ketertarikan Peserta } \\
\text { didik }\end{array}$ & 69,88 & 71,81 \\
\hline 3 & Perhatian & 73,63 & 74,84 \\
\hline 4 & $\begin{array}{l}\text { Keterlibatan Peserta } \\
\text { didik }\end{array}$ & 84,63 & 80,77 \\
\hline \multicolumn{2}{|c|}{ Rerata minat belajar } & 75,16 & 75,27 \\
\hline
\end{tabular}

Berdasarkan data di atas, diperoleh total capaian responden (TCR) dari minat belajar peserta didik, baik di kelas eksperimen ataupun di kelas control memiliki minat belajar yang sudah baik.

Setelah dilakukan eksperimen melalui penggunaan media yang berbeda di kelas yang menjadi sampel pada penelitian ini, maka diberikan tes akhir. Tes akhir yang diberikan ini bertujuan untuk melihat tingkat kemampuan peserta didik terhadap mata pelajaran Ekonomi setelah diberikan perlakuan yang berbeda. Tes akhir berbentuk tes pilihan ganda yang berjumlah 30 item pilihan ganda dengan rentangan 1-100. Data hasil belajar peserta didik di MAN 2 Batusangkar dapat dilihat dari tabel berikut:

Tabel 2. Deskripsi Perbandingan Hasil Belajar Peserta didik Kelas Eksperimen dan Kelas Kontrol

\begin{tabular}{|l|c|c|c|c|c|}
\hline \multirow{2}{*}{ No } & \multirow{2}{*}{ Interval } & \multicolumn{2}{|c|}{ Kelas Eksperimen } & \multicolumn{2}{|c|}{ Kelas Kontrol } \\
\cline { 3 - 6 } & & $\mathrm{Fi}$ & $\%$ & $\mathrm{Fi}$ & $\%$ \\
\hline
\end{tabular}




\begin{tabular}{|c|c|c|c|c|c|}
\hline \multirow{2}{*}{ No } & \multirow{2}{*}{ Interval } & \multicolumn{2}{|c|}{ Kelas Eksperimen } & \multicolumn{2}{|c|}{ Kelas Kontrol } \\
\hline & & $\mathbf{F i}$ & $\%$ & $\mathbf{F i}$ & $\%$ \\
\hline 1 & $63-68$ & 1 & 3,13 & 2 & 6,45 \\
\hline 2 & $69-74$ & 6 & 18,75 & 6 & 19,35 \\
\hline 3 & $75-80$ & 15 & 46,88 & 17 & 54,84 \\
\hline 4 & $81-86$ & 3 & 9,38 & 3 & 9,68 \\
\hline 5 & $87-92$ & 6 & 18,75 & 3 & 9,68 \\
\hline 6 & $93-98$ & 1 & 3,13 & 0 & 0,00 \\
\hline \multicolumn{2}{|c|}{ Total } & 32 & 100 & 31 & 100 \\
\hline \multicolumn{2}{|c|}{ Mean } & & 79,84 & & 77,06 \\
\hline \multicolumn{2}{|c|}{ STD } & & 6,55 & & 6,28 \\
\hline \multicolumn{2}{|c|}{ Max } & & 97 & & 90 \\
\hline \multicolumn{2}{|c|}{ Min } & & 67 & & 63 \\
\hline
\end{tabular}

Berdasarkan hasil di atas, dapat disimpulkan bahwa hasil belajar kelas eksperimen lebih tinggi dibandingkan dengan kelas kontrol, dimana pada kelas eksperimen nilai rata-rata sebesar 79,84 dengan nilai paling tinggi yang diperoleh sebesar 97 dan pada kelas kontrol sebesar 77,06 dengan nilai paling tinggi yang diperoleh sebesar 90. Jadi hasil belajar peserta didik yang diajarkan dengan menggunakan media visual proyeksi dengan Power Point lebih baik dibandingkan dengan peserta didik yang diajarkan dengan menggunakan media visual non-proyeksi dengan Chart.

Kemudian data penelitian yang diolah dapat diketahui berdistribusi normal dan homogen, maka langkah selanjutnya penulis meneruskan pada analisis varians dua jalur.

1) Hipotesis pertama: Peserta didik yang diajar dengan menggunakan media Visual Proyeksi dengan Power Point secara signifikan akan memiliki hasil belajar yang lebih tinggi dibandingkan dengan peserta didik yang diajar dengan media Non-Proyeksi dengan Chart.

Beradasarkan hasil olahan analisis varians dua jalur, maka didapat nilai Fhitung sebesar 8,876 lebih besar dibandingkan dengan $\mathrm{F}_{\text {tabel }}=4,00\left(\mathrm{~F}_{\text {hitung }}\right.$ $\left.>\mathrm{F}_{\text {tabel}}\right)$ atau pada level sig. 0,004 ini berarti bahwa Ho ditolak. Ini artinya pembelajaran menggunakan media visual proyeksi dengan Power Point memiliki pengaruh yang signifikan terhadap hasil belajar mata pelajaran Ekonomi peserta didik kelas X di MAN 2 Batusangkar. Jadi, pembelajaran dengan menggunakan media visual proyeksi dengan Power Point lebih baik dibandingkan pembelajaran yang menggunakan media visual non-proyeksi dengan Chart. Ini sesuai dengan pendapat Hamalik (2004) yang menyatakan bahwa untuk mencapai tujuan pembelajaran yang baik dapat ditunjang dengan adanya media belajar, karena dengan menggunakan media pembelajaran dapat menciptakan efisiensi proses dan dan mutu hasil belajar. Hal ini juga dibuktikan oleh hasil penelitian Srimaya (2017) yang menemukan bahwa pemanfaatan media pembelajaran Power Point lebih efektif dalam meningkatkan hasil belajar peserta didik. Jadi dapat disimpulkan bahwa, peserta didik yang diajarkan dengan menggunakan media visual proyeksi Power Point akan lebih baik hasil belajarnya dibandingkan sebelum menggunakan media pembelajaran.

Dengan menggunakan media visual proyeksi Power Point ini dapat menarik perhatian peserta didik dalam memperhatikan tenaga pendidik dalam menyampaikan materi pelajaran, walaupun masih ada beberapa orang yang masih belum serius dalam belajar. Selain itu, peserta didik sudah mulai aktif bertanya mengenai materi yang kurang dipahami selama proses pembelajaran berlangsung dan mencatat pokok bahasan yang disampaikan oleh tenaga pendidik, kemudian mampu menjawab pertanyaan dari tenaga pendidik. Ini memperlihatkan bahwa peserta didik sudah mulai terangsang dalam mengikuti pembelajaran di kelas. Ini sesuai dengan pendapat Lesle J. Briggs dalam Sanjaya, (2009:204), yang menjelaskan bahwa alat yang bisa merangsang peserta didik untuk mengikuti proses pembelajaran adalah dengan menggunakan media pembelajaran. Proses pembelajaran juga berlangsung baik karena pesan pelajaran yang dibuat dengan program Power Point 
tampak jelas oleh peserta didik semuanya karena pesan yang disampaikan menggunakan alat proyeksi atau proyektor yang membuat pesan pelajaran yang disampaikan oleh peserta didik tampak lebih besar dari ukuran sebenarnya. Ini sesuai dengan pendapat (Asyhar, 2011:66) yang menyatakan bahwa untuk menampilkan objek atau pesan pada layar monitor dengan ukuran yang lebih besar dari ukuran aslinya, sehingga akan lebih mudah dilihat dan diamati peserta didik dalam pembelajaran maka digunakan proyektor. Berdasarkan hal tersebut, dapat disimpulkan bahwa media visual proyeksi dengan Power Point baik digunakan untuk membantu dalam memperbaiki hasil belajar Ekonomi peserta didik.

2) Hipotesis kedua: Hasil belajar peserta didik yang memiliki minat belajar tinggi secara signifikan akan memiliki hasil belajar yang lebih tinggi dibandingkan dengan peserta didik yang memiliki minat belajar yang rendah.

Berdasarkan hasil olahan analisis varians dua jalur diperoleh nilai $F_{\text {hitung }}$ sebesar 56,197 lebih besar dibandingkan dengan $F_{\text {tabel }}$ 4,00 pada level sig. 0,000 ini berarti bahwa nilai sig. lebih kecil dibandingkan dengan $\alpha=0,05$ maka Ho ditolak, ini berarti minat belajar memiliki pengaruh signifikan terhadap hasil belajar mata pelajaran Ekonomi peserta didik kelas X di MAN 2 Batusangkar.

Sesuai dengan hasil penelitian menunjukkan bahwa hasil belajar peserta didik yang mempunyai minat belajar tinggi akan lebih baik dibandingkan dengan hasil belajar peserta didik yang mempunyai minat belajar rendah. Pada kelas eksperimen, rata-rata minat belajar peserta didik yang dilhat dari keterlibatan peserta didik dalam pembelajaran sebesar 84, 44 dibandingkan dengan kelas kontrol sebesar 75,25, ini berarti minat belajar peserta didik di kelas eksperimen lebih tinggi dibandingkan dengan peserta didik di kelas kontrol.

Jadi, salah satu faktor yang dapat mempengaruhi hasil belajar seorang peserta didik adalah minat belajar dari peserta didik itu sendiri. Ini senada dengan pendapat Slameto (2003) yang menyatakan salah satu faktor internal yang dapat mempenagruhi hasil belajar peserta didik adalah minat belajar peserta didik itu sendiri. Sesuai dengan pernyataan tersebut maka dapat disimpulkan bahwa peserta didik yang mempunyai minat belajar yang tinggi, maka hasil belajarnya akan lebih baik dibandingkan dengan peserta didik yang mempunyai minat belajar yang rendah. Hal ini juga dibuktikan dengan penelitian yang telah dilakukan oleh Inooshi (2012), yang menyatakan bahwa peserta didik yang memiliki minat belajar tinggi, hasil belajarnya juga tinggi, dibandingkan dengan peserta didik yang memiliki minat belajar yang rendah.

3) Hipotesis ketiga: Terdapat interaksi antara pembelajaran menggunakan media dengan minat belajar terhadap hasil belajar Ekonomi.

Berdasarkan hasil olahan analisis varians dua jalur yang nilai $F_{\text {hitung }}$ sebesar 0,502 lebih kecil dibandingkan dengan $F_{\text {tabel }}$ 4,00 pada level sig. 0,482 ini berarti bahwa nilai sig. lebih besar dibandingkan dengan $\alpha=0,05$ maka Ho diterima, ini berarti penggunaan media pembelajaran tidak ada interaksi dengan minat belajar peserta didik kelas $\mathrm{X}$ di MAN 2 Batusangkar.

Berdasarkan hasil penelitian yang diperoleh dapat dilihat bahwa, pada kelas eksperimen dan kelas kontrol nilai ratarata hasil belajar peserta didik akan tinggi pada peserta didik yang memiliki minat belajar yang tinggi pula. Namun, hasil belajar peserta didik yang memiliki minat belajar tinggi di kelas eksperimen lebih tinggi dibandingkan hasil belajar peserta didik pada kelas kontrol, begitu pula sebaliknya. Ini menunjukkan bahwa 
diantara penggunaan media pembelajaran dengan minat belajar peserta didik tidak ada interaksi. Hal ini berarti masingmasing faktor, media pembelajaraan dan minat belajar peserta didik tidak berinteraksi mempengaruhi hasil belajar peserta didik. Dimana kedua faktor tersebut mempunyai posisi masingmasing terhadap hasil belajar. Pada suatu sisi mungkin saja penggunaan media dalam pembelajaran lebih menentukan hasil belajar, namun disisi lain mungkin saja minat belajar yang dapat mempengaruhi hasil belajar peserta didik.

Penggunaan media dalam proses belajar mengajar sebenarnya bisa merangsang peserta didik untuk mencapai efektivitasnya dalam belajar, sehingga hasil belajar peserta didik juga akan meningkat. Hal ini sejalan dengan pendapat Djamarah \& Zain (2010) yang menjelaskan kalau proses pembelajaran dan hasil belajar akan lebih baik apabila tenaga pendidik menggunakan media pembelajaran. Jika proses pembelajaran berlangsung dengan baik, maka minat belajar peserta didik bisa meningkat dan menyebabkan peserta didik lebih semangat dalam mengikuti proses pembelajaran. Ini sejalan dengan pendapat Jalius, (2009) yang menyatakan bahwa penggunaan media pembelajaran yang tepat pada saat proses pembelajaran akan dapat meningkatkan minat belajar peserta didik.

Namun kenyataan yang terjadi tidak seperti yang diharapkan, dimana dalam mempengaruhi hasil belajar peserta didik, penggunaan media dengan minat belajar siswa tidak terdapat interaksi. Tidak terdapatnya interaksi ini dapat disebabkan karena masih banyaknya kekurangankekurangan dari peneliti saat melakukan penelitian, seperti kurangnya sarana pendukung untuk mengoperasikan media tersebut dan masih kurangnya peneliti melibatkan peserta didik dalam menggunakan media secara langsung saat proses pembelajaran berlangsung, dimana peserta didik hanya sebagai penonton saja.

Berdasarkan penelitan yang sudah dikerjakan, bisa ditarik kesimpulan kalau masing-masing faktor yaitu media pembelajaran dan minat belajar peserta didik tidak saling tergantung dalam mempengaruhi hasil belajar peserta didik.

\section{KESIMPULAN DAN REKOMENDASI}

Sesuai dengan hasil penelitian dan pembahasan, dapat ditarik kesimpulan bahwa penggunaan media pembelajaran visual proyeksi Power Point dan minat mempengaruhi hasil belajar Ekonomi Peserta didik di MAN 2 Batusangkar, namun media pembelajaraan dan minat belajar peserta didik tidak berinteraksi mempengaruhi hasil belajar peserta didik, karenakedua faktor tersebut mempunyai posisi masing-masing terhadap hasil belajar

Berdasarkan hasil penelitian untuk meningkatkan hasil belajar ekonomi peserta didik di MAN 2 Batusangkar, di sini peneliti menyampaikan beberapa saran sebagai berikut:

1. Diharapkan kepada pihak sekolah:

a) Memberikan pelatihan kepada guru tentang pengembangan media visual yang menggunakan program Power Point, sehingga media yang ditampilkan oleh guru lebih menarik bagi peserta didik dan dapat meningkatkan hasil belajar dan minat belajar peserta didik.

b) Melengkapi fasilitas belajar yang dapat membantu guru dalam proses pembelajaran, seperti penyediaan proyektor LCD disetiap kelas.

2. Diharapkan kepada guru Bidang Studi Ekonomi:

a) Meningkatkan kemampuannya dalam menggunakan komputer sehingga mampu mendesain media yang berbasis komputer, seperti media visual proyeksi dengan Power Point.

b) Menggunakan media visual proyeksi dengan Power Point secara efektif dalam proses pembelajaran agar dapat 
meningkatkan minat belajar peserta didik.

c) Menggunakan media visual proyeksi dengan Power Point sebagai salah satu cara dalam meningkatkan hasil belajar peserta didik sehingga pemahaman peserta didik dalam mengikuti pelajaran Ekonomi dapat ditingkatkan.

\section{REFERENSI}

Asyhar, R. (2011). Kreatif Mengembangkan Media Pembelajaran. Jakarta: Gaung Persada.

Djamarah, S. B., \& Zain, A. (2010). Strategi Belajar Mengajar. Jakarta: PT. Rineka Cipta.

Hamalik, O. (2004). Psikologi Belajar mdan Mengajar. Bandung: Sinar Baru Algensindo.

Inooshi, D. D. (2012). Pengaruh Model Pembelajaran Kontektsual (Contextual Teaching and Learning) dan Minat Belajar Siswa Terhadap Hasil Belajar
Ekonomi Siswa Kelas XI IS Di SMA Negeri1 Padang Ganting Kab. Tanah Datar. (Tesis Unpublish). Padang: Jurusan Pendidikan IPS, Pasca Sarjana Univ.

Jalius, E. (2009). Pengembangan Program Pembelajaran. Padang: UNP Press.

Sanjaya, W. (2009). Perencanaan dan Desain Sistem Pembelajaran. Jakarta: Kencana.

Slameto. (2003). Belajar dan Faktor-faktor yang mempengaruhinya. Jakarta: PT. Rineka Cipta.

Srimaya. (2017). Efektifitas Media Pembelajaran Power Point untuk meningkatkan Motivasi dan Hasil Belajar Biologi Siswa. Biotek, 5(1), 5368.

Syafruddin. (2004). Buku Ajar Penilaian Hasil Belajar. Padang: Jurusan Ekonomi FIS Padang.

\section{Article Metadata:}

Febriyanti, S. (2019). The Effect of Visual Media of Power Point Projection and Students' Interest on Students' Learning Outcomes, 22 (1), 33-40.

http://dx.doi.org/10.31958/jt.v22i1.1191

Keywords Media, Power point, Insterest, Learning outcome

Coresponding author: Siska Febriyanti S, IAIN Batusangkar, siska_feb@ymail.com 